\title{
The Impact of Regulation on Corporate Hedging Activities and the Response of Corporates - A Preliminary Conceptual Framework
}

\author{
Henok Kifle ${ }^{1}$ \\ ${ }^{1}$ University of Gloucestershire, England \\ Correspondence: Henok Kifle, University of Gloucestershire, England
}

Received: September 21, 2017

Accepted: October 24, 2017

Online Published: October 30, 2017

doi:10.5430/bmr.v6n4p1

URL: https://doi.org/10.5430/bmr.v6n4p1

\begin{abstract}
Following the financial crisis of 2007/2008 regulators intensified the regulation of financial derivatives through (i) the implementation of the European Markets Infrastructure Directive (EMIR) to increase transparency of over-the-counter (OTC) derivatives and (ii) the implementation of Basel III to increase capital underpinning. Non-financial corporates, who mainly hedge with OTC derivatives, are seeing tendencies of increasing costs and decreasing availability of required OTC derivatives but fail to have a full concept of the impact and possible responses to manage the impact. Also, theoretical research did not consider reguation as an influencing factor and thus does not offer theories to analyse the impact of regulation on corporate hedging activities (defined as the willingness and ability of NFCs to conduct hedging in an optimal way). Given this gap, this paper reviews existing theories and based on that pre-conceptualises a model that helps to analyse the impact of regulation on corporate hedging activities and provides a preliminary conceptual framework that includes corporate responses to manage the regulatory impact.
\end{abstract}

Keywords: Corporate hedging, Regulatory impact, Derivatives regulation

\section{Introduction}

Financial market regulators intensified the regulation of financial derivatives, following the financial crisis of 2007/2008. The main measures include the implementation of European Markets Infrastructure Directive (EMIR) and Basel III to increase transparency of the over-the-counter (OTC) derivatives market and to increase capital underpinning of derivatives transactions. Non-financial-corporates (NFCs) are very much concerned about the impact of both regulations on their hedging activities which significantly rely on OTC derivatives. EMIR impacts the cost and effectiveness of hedging activities and requirements on systems given the various reporting and monitoring requirements and NFCs and as surveys and comments state, NFCs started seeing trends of higher costs for hedging and a decrease of availability of required derivatives due to Basel III.

For example, in February 2012, the Verband Deutscher Treasurer (the Association of German Treasurers, VDT) and Deutsches Aktieninstitut (German Shares Institute, DAI) surveyed 364 non-financial companies amongst their members with 205 respondents, of which $86.3 \%$ stated that banks clearly or at least by trend try to establish higher prices for hedging transactions via derivatives. $44.3 \%$ mentioned to sense that banks are urging towards the cash collateralization of OTC derivatives. Those NFCs mentioned to see trends that the availability of financial derivatives products is decreasing as banks apply a more selective deployment of their scarce equity capital. 26.9\% of respondents mentioned that the number of banks that are willing to provide hedging instruments has declined and $30 \%$ stated that it is more difficult to get the appropriate hedging instruments for their transactions. The availability of longer term hedging instruments has been declining significantly as $56.3 \%$ of respondents mentiooned.

Furthermore, key findings of an online survey of European corporate treasury professionals conducted in January 2012 by EuroFinance stated that: (i) $57 \%$ of corporates in western Europe expect that the implementation of Basel III regulations will have a negative impact on their company's performance, and (ii) $61 \%$ of European corporate treasurers, who expressed an opinion, think that banking regulators do not understand the impact of their regulations on corporate and trade finance.

Nevertheless, NFCs fail to have a full overview of the impact on their corporate hedging activities - which is defined in this study as the willingness and ability of NFCs to conduct hedging in an optimal way. Such overview has also 
not been brought forward by theoretical literature but is of interest for practioners, theorists, regulators and other policy makers. This review aims to suggest such an overview through pre-conceptualisation of a model that helps to analyse the impact of regulation on corporate hedging activities and a framework that integrates such model and possible corporate responses to manage the impact. The review is divided in three sections. The first section is concerned with the pre-conceptualisation of a model to analyse the impact of the regulatory changes on corporate hedging activities. For that relevant literature on corporate hedging is reviewed. The findings are applied to develop a preliminary impact analysis model. The second section is concerned with concepts of organisational response to regulation. For that the review is widened into strategic management fied, where most of the theories on organisational response to regulation are to find. The result of that is an initial conceptual framework on management of regulatory involvement. The third section integrates the first and second sections and creates an integrated initial conceptual framework that can guide further research.

\section{Corporate Hedging and Corporate Hedging Activities}

This section aims at the pre-conceptualisation of a model to analyse the impact of regulatory changes on corporate hedging activities. For that existing literature on corporate hedging is critically reviewed with regards to relevant ideas and concepts related to corporate hedging activities. In this context pre-conceptualisation is understood as a preliminary impact analysis model. After defining corporate hedging and corporate hedging activities, the most relevant theories related to the reasons for corporates to conduct corporate hedging as well as the optimal way of corporate hedging are critically reviewed with the aim to extract factors that might be of relevance for the impact analysis model.

\subsection{Definition of Corporate Hedging and Corporate Hedging Activities}

Spanò (2013) and Gupta (2017) summarized the three different definitions of corporate hedging that can be derived from theoretical literature as the following: (i) hedging as a generic insurance contract, (ii) hedging as any action reducing covariance between a firm's value and a state contingent variable or, more specifically, (iii) hedging as the activity of holding derivative financial instruments to reduce the exposure to marketable risks. The latter is the most specific definition and is of relevance for this paper.

\subsubsection{Hedging as an Insurance Contract}

Mayers and Smith (1982) published the journal article "On the Corporate Demand for Insurance", which is broadly considered as the first study that introduced corporate risk management into the modern theory of corporate finance. The study's view of hedging was as an insurance contract. Mayers and Smith regarded the corporation as a sort of primary market of explicit and implicit long-term contracts between different claimholders: shareholders, bondholders, employees, customers and suppliers. Mayers and Smith (1982) argued that due to the contracting costs, it is optimal for corporations to allocate risk to those claimholders that have a comparative advantage in risk bearing. In their view these claimholders were the stockholders and bondholders, as they can diversify their claims through the secondary market. However, as the amount of risk that can be allocated to stockholders and bondholders is limited by the amount of capital of the firm, Mayers and Smith (1982) suggested that the purchase of insurance (corporate hedging) offers the possibility to reallocate risk from the other claimholders to the insurance company.

\subsubsection{Hedging as Any Action Reducing Correlation}

Smith and Stulz (1985) brought the definition of hedging a step further. In their study "The determinants of firms' hedging policies", they refer to hedging as reducing risk by holding derivative financial instruments but also by other ways, such as a merger or operational and capital structure changes or a change in real operating decisions. Thus, Smith and Stulz consider hedging to be any action that reduces or eliminates the covariance between the firm's value and the value of a generic state variable. Smith and Stulz (1985) argue that their approach to hedging is different compared to the insurance-like approach of Mayers and Smith (1982), because - in contrasts to hedging through forwards and futures - for corporations the purchase of insurance provides real services, given the expertise of insurance companies in evaluating risks and administering claims settlement. However, their definition is sufficiently broad to include the insurance-like definition of Mayers and Smith (1982) among the actions defined as hedging, as an insurance contract is a possible means to reduce the covariance between the firm's value and a state variable.

\subsubsection{Hedging as Holding Derivative Financial Instruments}

The most recent definition, which also of relevance for pre-conceptualisation of the model, explicitly refers to hedging as the act of holding derivative financial instruments (Gupta, 2017). Authors, such Froot, Scharfstein, and Stein (1993), DeMarzo and Duffie (1995), Broll and Eckwert (1999) and Battermann, Braulke, Broll, and Schimmelpfennig (2000) regarded hedging as the act of holding derivative financial instruments to reduce or 
eliminate the covariance between the firm's value and the value of an underlying asset subject to market price fluctuations. Their primary interest is often the investigation of the different effects of different derivative financial instruments, for example to derive the preferred hedge strategy (Battermann et al., 2000; Froot et al., 1993). As Spanò (2013) and Gupta (2017) pointed out, this type of definition implies the absence of asymmetric information and moral hazard problems, underlining a peculiarity of purchasing derivatives with respect to purchasing insurance contracts, which cannot be captured by the general definition of Smith and Stulz (1985). Thus, following definitions apply for the initial impact analysis model:

- Corporate hedging: The Act of holding derivative financial instruments by non-financial corporations to reduce or eliminate the covariance between the firm's value and the value of underlying assets which are subject to foreign exchange risk and interest rate risk fluctuations.

- Corporate Hedging Activity: This study is interested into the impact of regulation on the willingness of NFCs to conduct corporate hedging as well as the influence on the ability of NFCs to conduct hedging in a way that optimal for the respective NFC. Thus, corporate hedging activity in this study is defined as: the willingness and ability of a non-financial corporation to conduct Corporate Hedging.

\subsection{Rationale for Corporate Hedging}

Studies that explain the reasons for NFCs to hedge are used to understand and extract the key elements of the willingness of NFCs to conduct corporate hedging, which is one part of the impact analysis model. Gupta (2017) and Spanò (2013) summarized the existing theories and differentiated them into two groups, both of them aiming to increase profits/wealth by reducing costs associated with volatility. The first group connects corporate hedging to the objective of the firm to maximise shareholder wealth, and the second focusses on hedging as a mean to maximise managers' private utility.

Table 1. Rationales for Corporate Hedging

\begin{tabular}{lcl}
\hline Rationales & Method \\
\hline Shareholder wealth increase & - Reduction of costs of financial distress \\
& $-\quad$ Reduction of agency costs of debt \\
& - Reduction of pre- tax liability \\
& $-\quad$ Reduction of costs of external financing \\
Managers private utility & - Increase own income/wealth by letting firm hedge volatility \\
& - & Reputation of managerial performance \\
\hline
\end{tabular}

2.2.1 Corporate Hedging to Maximise Shareholder Wealth

\section{a) Cost of financial distress}

Introduced by Smith and Stulz (1985) in their above-mentioned study, this theory suggests that hedging reduces the probability of default and thus the present value of the costs of financial distress. This can be done by reducing the volatility of the firm's cash flows as the present value of the cost of financial distress is a function of the probability of default and the costs given default (Omar, Mohammad, \& Ahmad, 2017; Stulz, 2013). Furthermore, Smith and Stulz have argued that, while the reduction of financial distress cost increases firm value, it augments shareholder value even further by simultaneously raising the firm's potential to carry debt. Hedging lowers the cost of financial distress, which leads to a higher optimal debt ratio and the tax shields of the additional debt further increases the value of the firm. However, they have also mentioned that as shareholders have no possibility to reduce these costs, in the presence of costs of bankruptcy, management has a comparative advantage in managing risk.

Several studies have investigated empirical evidence for the financial distress argument by analysing the relationship between financial constraints and firms' hedging activities. While for example Nance, Smith, and Smithson (1993) and Sprčić (2008a) did not find evidence supporting the financial distress argument, other studies found evidence that firms with lower liquidity and higher leverage are more likely to use derivatives. Among others following studies have found evidence, Dolde (1995), Mian (1996), Fok, Carroll, and Chiou (1997), Goldberg, Godwin Kim Tritschler, and Myung-Sun (1998) and Haushalter (2000), Judge (2002), Fehle and Tsyplakov (2005), Singh and Upneja (2008), Afza and Alam (2011), Adam, Fernando, and Salas (2015) and Judge (2015). 
b) The agency cost of debt

In their study about managerial behaviour, agency costs and ownership structure, Jensen and Meckling (1976) brought forward that firms can decrease agency costs of debt by reducing the volatility of cash flows. Dobson and Soenen (1993) presented three reasons to hedge risk based on agency costs: (i) hedging reduces uncertainty as it smooth future cash flows and by doing this lowers the firm's cost of debt. (ii) when debt financing, cash flow smoothing by hedging exchange risk will tend to reduce the risk-shifting (from shareholders to bondholders) and underinvestment problems (rejection of positive net present value projects if return is mainly to bondholders) and by that reduce agency cost of debt, and (iii) hedging extends the length of the contractual relations between shareholders by reducing the probability of financial distress. It mitigates the moral-hazard agency problem by contributing to corporate reputation.

This rationale is supported by empirical evidence of various studies such as Bessembinder (1991), Minton and Schrand (1999), Haushalter, Heron, and Lie (2002), Judge (2002), Singh and Upneja (2008), Ameer (2010), Afza and Alam (2011), Chaudhry et al. (2014), Deng, Elyasiani, Mao (2016) and Alexandridis, Chen, and Zeng (2017) while Sprčić (2008a) did not find supporting evidence with regards to Croatian and Slovenian companies.

c) The convexity of the tax function

Smith and Stulz (1985) brought forward the argument that hedging can increase firm value depending on the tax code that the firm faces. While the expected tax liability of a firm, facing a linear tax function (constant effective marginal tax rate), is unaffected by the volatility of taxable income, this changes in the case of a convex tax structure. A tax system can be convex in cases where the marginal tax rate increases progressively with taxable income or due to various tax rules and regulation (Bartram, 2000).

Smith and Stulz (1985) argue that if a firm faces a convex tax function, i.e. the marginal corporate tax rates are an increasing function of the firm's pre-tax value, then the after-tax value of the firm is a concave function of the pre-tax value. By reducing the variability of pre-tax firm values hedging can reduce the expected tax liability and subsequently increase the expected post-tax value of the firm, if hedging costs are not too large. Activities which reduce the volatility in reported earnings will enhance shareholder value by reducing the effective long run average tax rate and the more convex the effective tax system, the greater the reduction in expected taxes, a rationale supported among others by Froot et al. (1993), Mian (1996), Graham and Smith (1999).

The empirical evidence supporting this argument is rather limited with, Berkman, Bradbury, and Magan (1997), Judge (2002), Afza and Alam (2011), having found some support of that theory in their respective samples of New Zealand, UK and Pakistani firms, while other did not found empirical support.

d) Costly external financing

In this theory funds obtained from external sources are assumed more expensive than internal funds because of capital market imperfections (such as transaction costs and agency costs) and stabilizing a firm's cash flows through hedging can be value increasing as it improves the probability of having sufficient internal funds for planned investments and avoiding the need either to cut profitable projects or bear the transaction costs of obtaining external funding (Froot et al., 1993). As explored by numerous scholars, such as Stulz (1990), (Haushalter et al., 2002) and summarized by Glaum (2002), this rationale for hedging is more relevant, (i) the larger a firm's growth options, (ii)the more pronounced the informational asymmetries between management and investors and between different types of claim holders, and (iii)tThe higher the cost of external funding.

Based on that theory and on evidence that internal cash flow is correlated to corporate investment, Froot et al. (1993) produced a model where the costly external financing can result in underinvestment in some situation, namely when internally generated funds fall short to cover the amount of profitable new investments. Thus, the volatility of profits can lead to a shortage of funds and cause the firm to seek costly external financing for their investments in low-profit times. This in turn reduces in Froot et al.'s model the optimal investment in low profit situations and firms can aim for hedging strategies that reduce the volatility of earnings.

A huge number of studies have presented evidence that provides support for this rationale to hedge, amongst others Fok et al. (1997), Goldberg et al. (1998), Haushalter et al. (2002), Sprčić, Tekavčič, and Šević (2008b), Singh and Upneja (2008), Afza and Alam (2011), Chernenko and Faulkender (2012), Chaudhry et al. (2014), Deng et al. (2016).

\subsubsection{Corporate Hedging as a Mean to Maximise Managers' Private Utility}

This line of reasoning, introduced by Stulz (1984), refers to the incentives of managers to hedge their own wealth on the expense of shareholders. Significant portions of manager's wealth, in the form of income or share ownership, are 
linked with the economic situation and financial performance of the firm. Thus, other things being equal, managers prefer stability to volatility to improve their own wealth (Jensen \& Meckling, 1976). Smith and Stulz (1985) pointed out, that as managers are not fully diversified, they have an incentive to hedge the risks inherent in their own position, and since hedging involves costs, they prefer the firm to hedge them. Against the background that managers might otherwise reject to undertake positive but risky net-present-value projects, the implementation of a risk management programme may also be in the shareholders' interest (Glaum, 2002). A further reason, why management may prefer to hedge, focusses on managers' reputation. Managers may prefer to implement a risk management programme to communicate their managerial performance to outside observers without income volatility which is not in their control (Bodnar et al., 2016; Breeden \& Viswanathan, 1998; DeMarzo \& Duffie, 1995).

Empirical evidence for this rationale are inconclusive, e.g. Berkman et al. (1997), Sprčić (2008a), Huang and Li (2014) did not find supporting evidence, while Tufano's (1996), Ertugrul, Sezer, and Sirmans (2008), Singh and Upneja (2008), Ameer (2010), Afza and Alam (2011), Sang, Abu, and Osman (2013), and Bodnar et al. (2016) found supporting evidence.

\subsection{Optimal Hedging Strategy}

Further inside into the elements that might influence the willingness and ability of NFCs to hedge can be found in theories that deal with the optimal way of hedging, defined for that purpose as the choice of the right hedging instrument, hedge ratio and tenor. With regards to the derivatives choice, finance literature generally differentiates between linear and non-linear instruments. Derivatives with linear payoff structure (payoff function has a linear relationship to the price of the underlying asset) such as futures, forwards and swaps can inexpensively transfer risk and reduce variance of cash flow. Non-linear derivatives, such as options, can reduce downside risk while allowing upside potential and can be used for yield or income enhancement (Hopkin, 2017).

Some seminal contributions have provided theoretical models that explain the optimality of one type of hedging strategy relative to the other including the optimal hedging strategy when linear instruments are chosen or when non-linear instruments are chosen (Bajo, Barbi, \& Romagnoli, 2012). However, there is no single uniformly accepted model and most cited theoretical models have been set up within different contexts (Gupta, 2017; P. Huang, 2003; Mnasri, Dionne, \& Gueyie, 2013; Spanò, 2013). Subsequently empirical evidence and results are mixed. However, below elaborations dwell on the most cited models, as summarized by Mnasri et al. (2013), and will analyse their possible contribution to the pre-conceptualisation of the impact analysis model.

Adler and Detemple (1988) argued that, to achieve optimal hedging, non-diversified managers with no limitation on borrowing and short-selling opportunities will adopt to linear strategies while investors that face borrowing constraints have incentives to use non-linear instruments. Froot et al. (1993) looked on corporate risk management in the context of firm-value maximization. They developed a model (FSS Model) that aims to show how a firm's optimal hedging strategy - in terms of both the amount of hedging and the instruments used - depends on the nature of their investment and financing opportunities and is set up in different settings. Mello and Parsons (2000) have developed a model (MP model) for evaluating alternative hedging strategies for financially constrained firms. Adam (2002) extended the FSS model and MP model to a multi-period framework and. Adam (2009) investigated the reason of usage of options strategies instead of linear strategies and confirmed the findings in Adam (2002).

Some models also included production and pricing characteristics of the company's output. Moschini and Lapan (1992) looked on the linear instrument vs. non-linear instrument choice for a competitive firm with production flexibility. Brown and Toft (2002) modelled a profit-maximizing firm that is confronted with both price and quantity uncertainties and financial distress. Gay, Nam, and Turac (2002) and (2003) examined how corporations should choose their optimal mix of linear and non-linear derivatives with price and quantity risk.

Overall, despite the existence of many theoretical models, empirical evidence is rather scant and mixed, perhaps because models have been set up in different contexts (Mnasri et al., 2013). As a key takeaway of this section, below table and explanation summarizes the key determinants of the most cited theoretical models on optimal hedging strategy. Those determinants will then be critically reviewed with regards to their ability to contribute to the initial impact analysis model. 
Table 2. Literature on optimal corporate hedging strategy

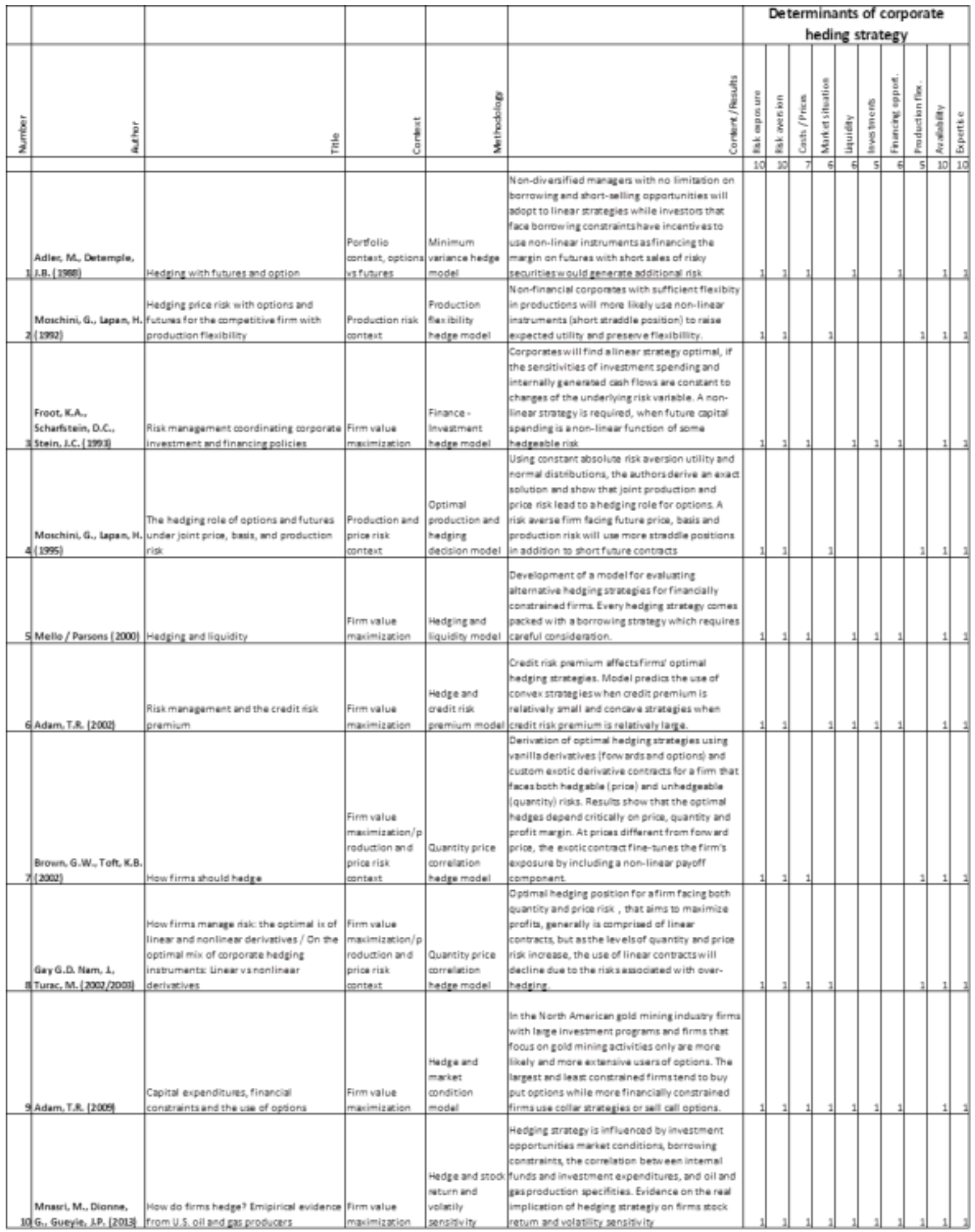

Following factors have been extracted from the above mentioned theoretical models as key factors with regards to the optimal hedging strategy:

1. Risk exposure: The type of risk that the company is exposed to (interest rates, foreign exchange rates etc.) is the starting point for each hedging decision and as such mentioned in all models. This also includes the pay-off structure, i.e. linear and non-linear exposure. 
2. Risk aversion: A risk-averse attitude of corporates to financial risk is assumed by all models.

3. Costs / prices: While neglected by some models due to simplicity reasons, most studies consider costs as a key factor. This includes all the costs that are associated with entering the hedging transactions.

4. Market situation/expectation: Mentioned by six studies, this factor includes decision maker's expectations and opinions with regards to the development of the market and the risky asset or cash flows.

5. Liquidity: More than half of the studies regard the available liquidity as an important factpr or as one of the main aims of the model, namely to ensure the company's ability to meet its cash flow commitments.

6. Investments: Half of the studies mentioned that investments and financings are key factors with regards to the optimal hedging strategy as they can determine the risk exposure.

7. Financing opportunities and costs: In the same context as the investments, the supply of external finance at beneficial prices is regarded as an important element of corporate hedging strategy as it can offset shortfalls of internal cash flows or allow pursuing further investment opportunities.

8. Production flexibility: The studies that approached the field in the context of production risk brought forward that available flexibility on the production side can (partly) offset the spot price risk of the output of corporates.

9. Availability: A factor which is implicitly a significant element in all models is the availability of the required derivatives instruments and the required tenor. Most of the models are based on one or two period models. However, the risk that corporates face is often more than one or two years.

10. Expertise/systems: This element goes in the same direction as availability. All models assume that the corporates do have the necessary expertise and systems to make out and handle the right strategy with derivatives.

\subsection{Preliminary Impact Analysis Model}

In this section, the above mentioned key factors will be reviewed with regards to their contribution to the preliminary Impact Analysis Model. From a change management perspective, R. S. Arnold and Bohner (1993) defined impact analysis as the activity of identifying what to modify to accomplish a change, or of identifying the potential consequences of a change. For the purpose of this study, impact analysis is defined in line with the second definition of R. S. Arnold and Bohner (1993). Thus, Impact Analysis is defined as the activity of identifying the potential consequences of a change. The model will have a micro approach, meaning that the key concept of the model (Corporate Hedging Activity) will be disaggregated in its constituent elements and the impact of regulation on each of the elements will be analysed. Thus, the model will constitute of the factors determining the willingness and the ability of NFCs to conduct corporate hedging.

The theories on rationales for hedging suggest that the reason to hedge is maximisation of profits and subsequently firm value. This is done through elimination of volatility of cash flows and reduction of financial and tax costs. This shows that shareholders' and managers' risk aversion (elimination of volatility) is the basis for any risk decion. Thus, the following is proposed:

\section{P1: The risk aversion of shareholders' and managers' influences the willingness of NFCs to do corporate hedging.}

As NFCs are replying to volatility of cash flows by hedging through derivatives, there must be a certain level of trust, in terms of security, into the derivatives market and the counterparty that is trading with them. Otherwise, NFCs would not feel more secure after the hedging with derivatives. Therefore, the following is proposed:

P2: The degree of trust into the derivatives market influences the willingness of NFCs to do corporate hedging.

The theories on the rationales for corporates to hedge show that firms aim to reduce or control costs (financial costs and/or tax costs). Thereby they aim to increase firm value. Therefore, it can be assumed that costs considerations also impact the willingness of NFCs to hedge through derivatives. As a result, the following is proposed:

P3: Cost considerations influence the willingness of NFCs to do corporate hedging.

With regards to the ability of NFCs to hedge, an important factor which is assumed as given in the above theoretical models is that the NFCs have the appropriate systems and processes in place. This includes the technological means buz also the appropriate processes, including guidelines or policies. Thus, the following is proposed:

P4: The systems and processes of NFCs in relation to corporate hedging influence their ability to conduct corporate hedging.

The theories on optimal hedging strategy suggest that the expertise of the employees, that do the hedging, and hedging policy deciders are of importance. At all stages of the corporate hedging transaction, that is from calculating 
the risk exposure, to determining the appropriate hedge ratio and choosing the right instrument, the know-how of the employees and management play a major role. Consequently, the following is proposed:

P5: The knowhow of NFCs with regards to corporate hedging influence their ability to conduct corporate hedging.

Another determinant that is assumed as a static factor in the above mentioned theoretical models is the availability of the required instruments and the required tenors. This is of course dependent on the derivatives markets' situation. Thus, also the situation on the derivatives market, be it directly the market or via the banks, can influence the ability of NFCs to conduct corporate hedging. Therefore, the following is proposed:

P6: The derivatives market situation influences the ability of NFCs to conduct corporate hedging.

Based on the above-mentioned suggestions, a preliminary model is created that should help analysing the impact of the regulatory changes on NFCs corporate hedging activities with the blue boxes representing the willingness to hedge and the green boxes the ability to hedge in an optimal way.

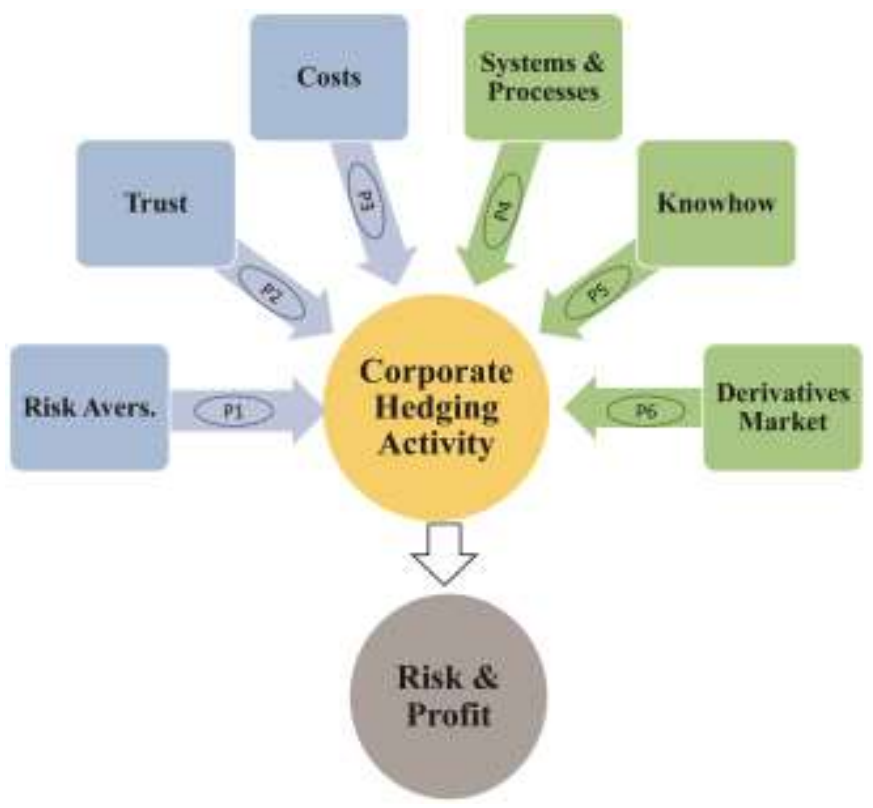

Figure 1. Preliminary impact analysis model

With regards to the relationship of the corporate hedging activities and the risk/return consideration, the theories on rationales to hedge have shown that firms hedge to increase firm value. Therefore, hedging has a positive impact on risk reduction and subsequently securing certain level of profits. Following this, less hedging might have a negative impact on risk and subsequently lead to more volatility of profits. Thus, if the impact of the regulatory changes is leading to a reduction of the hedging activity, it will increase the firms risk position and might have negative consequences on profits and firm value.

\section{Organisational Response to Regulation}

The following section reviews studies that can provide a framework on how NFCs will respond to regulatory impact on their hedging activities. Given the lack of a theoretical framework in the financial risk management field, the search is expanded to the strategic management filed. It starts by outlying the general importance of regulation when it comes to the strategic options of firms and goes then over to the concept of organisational response to regulations.

\subsection{Strategy and Regulation}

The significance of the general environment (which includes regulation) when it comes to a firm's strategic options was always of significant interest for strategy scholars and has been researched from different perspectives. Over the last sixty years, the literature and research on strategic management spread out leaving a diversity of partly competitive and partly complementary paradigms (Özleblebici \& Çetin, 2015; Tansey, Spillane, \& Meng, 2014; Volberda \& Elfring, 2001). Influential studies can be differentiated in those that focussed their studies on the importance of the environment for opportunities and threats and for positioning the firm with regards to competition such as Ansoff (1965), Andrews (1971), Porter (1979), and those that emphasized the different roles of organizational members when generating strategies such as Mintzberg (1987), Burgelman (1983a) and Hart and Banbury (1994). 
With regards to governmental and regulatory involvement studies show that it is together with ownership structures the major considered external actor when generating the corporate strategy, structure and processes (Frankenberger, 2006). In his study on the influences of external, regulatory actors on corporate strategy and structure Frankenberger (2006) categorized the literature regarding the impact of governmental/regulatory involvement in five clusters, namely: (1) internal effects, in the form of adjustments of corporate strategy and structure; (2) external effects in the form of externally directed strategic responses of corporations; (3) proactive political strategies to influence the legislation and regulation process; (4) interactive strategies involving multiple actors; (5) macro level studies. He found that most of the studies fall into the first cluster and are concerned with environmental regulations. The first cluster, namely internal effects on the corporate strategy and structure, is also of interest with regards to the aim of this study, namely to explore the response of NFCs to the regulation in terms of adjustments of strategy and structure.

\subsection{Concepts of Organisational Responses}

With regards to organisational responses to regulation, a milestone study which is cited by various studies (e.g. Chattopadhyay, Glick, and Huber (2001); Frankenberger (2006); Saebi, Lien, and Foss (2016); Vest and Kash (2016)) is the study of Cook, Shortell, Conrad, and Morrisey (1983). They discussed in their paper "A theory of organizational response to regulation: the case of hospitals" the type and timing of internal adjustments made by hospitals and patterns of inter-organizational activity within the framework of regulatory constraints. Cook et al. (1983) provide a general theory of organizational response to regulation, which is illustrated using the hospital industry. The theory consists of two major components, (i) the conceptualisation of the nature of regulatory process into four dimensions (scope, restrictiveness, degree of uncertainty and duration) which reflects the intensity of the regulation and (ii) the organisational response, in the form of an adaption and mutual selection perspective. The adaptation perspective deals with the efforts made by organisations to adapt to changing environmental circumstances and the selection perspective deals with the constraints set by the environment, limiting the adaption process (Cook et al., 1983). Furthermore, Cook et al. (1983) differentiated three levels of organizational level responses to regulation, namely institutional, managerial and technical and suggest that there is a hierarchical ordering of hospital responses to regulation that constrains financial resources, in view of the relative costliness of making the organizational changes. The theory predicts that organisations will first make internal adjustments at institutional level, followed by managerial level changes, and only as regulation, which is also influenced by other exogenous factors such as political climate, increases in intensity will changes be made at the technical level (Cook et al., 1983).

Table 3. Examples of Various Organisational Responses to Regulation

\begin{tabular}{|c|c|c|}
\hline & Intrahospital Regulatory Response & Interhospital Regulatory Response \\
\hline $\begin{array}{l}\text { Institutional Level } \\
\text { Response }\end{array}$ & $\begin{array}{ll}\text { - } & \text { Lawsuits } \\
\text { - } & \text { Hospital involvement with regulatory } \\
\text { agencies } & \\
\text { - } & \text { Trustee education program }\end{array}$ & $\begin{array}{ll}\text { - } & \text { Multiunit hospital system involvement } \\
\text { - } & \text { Merger, Consolidation, alliances } \\
\text { - } & \text { Hospital association activity }\end{array}$ \\
\hline $\begin{array}{l}\text { Managerial Level } \\
\text { Response }\end{array}$ & 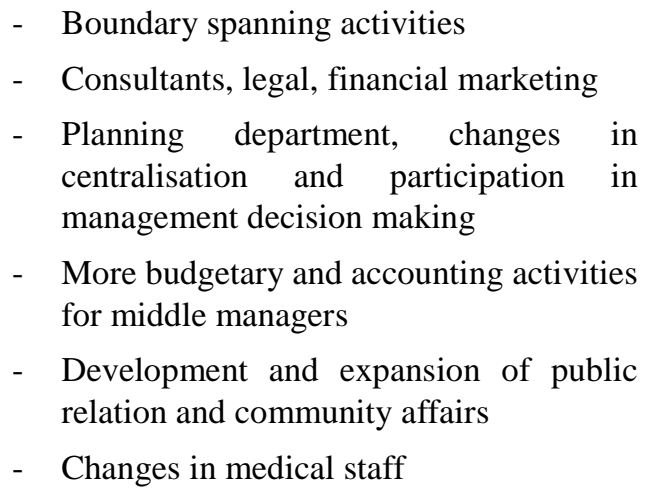 & 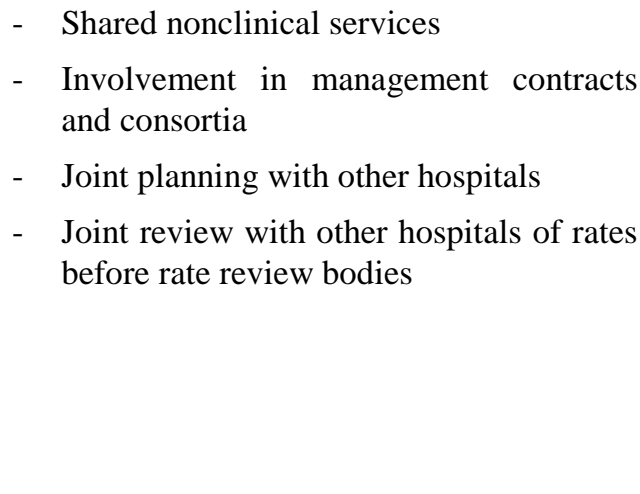 \\
\hline $\begin{array}{l}\text { Technical } \\
\text { Response }\end{array}$ & $\begin{array}{l}\text { - } \begin{array}{l}\text { Development of new services and } \\
\text { programs }\end{array} \\
\text { - Changes in scheduling, pricing, staffing, } \\
\text { practices, concentration of output etc. }\end{array}$ & $\begin{array}{l}\text { - } \quad \text { Shared clinical services } \\
\text { - } \quad \text { Shared medical staff arrangement }\end{array}$ \\
\hline
\end{tabular}


According to that theory, in the earlier and milder form of the regulation, organisations will try to mitigate the uncertainty created by regulatory changes through mechanisms such as educating trustees, attempting to become involved in the process and testing the legality of the imposed regulation through lawsuits. As the regulation persists, organisational response will go over to acquiring additional expertise and input and thereby developing greater boundary spanning capability for dealing with the regulatory environment (Cook et al., 1983).

The theory continues that organisations will try to avoid technical level responses and make them only as regulation increases in intensity. Rationale for that is that those changes go into the core of the products and services provided by the organisation and include an adjustment in the actual services and products provided, in staffing, scheduling and so on and organisations will try to protect their technical core, given that any modifications in that are costlier and they are the type of changes that the professionals in the organisation care the most about (Cook et al., 1983). The theory notes that contextual variables such as ownership structure might influence the response and further predicts, that only after exploring all the intra-organisational responses, organisations will consider making inter-organisational response. Figure 2 below presents the theory of organizational response to regulation according to Cook et al. (1983).

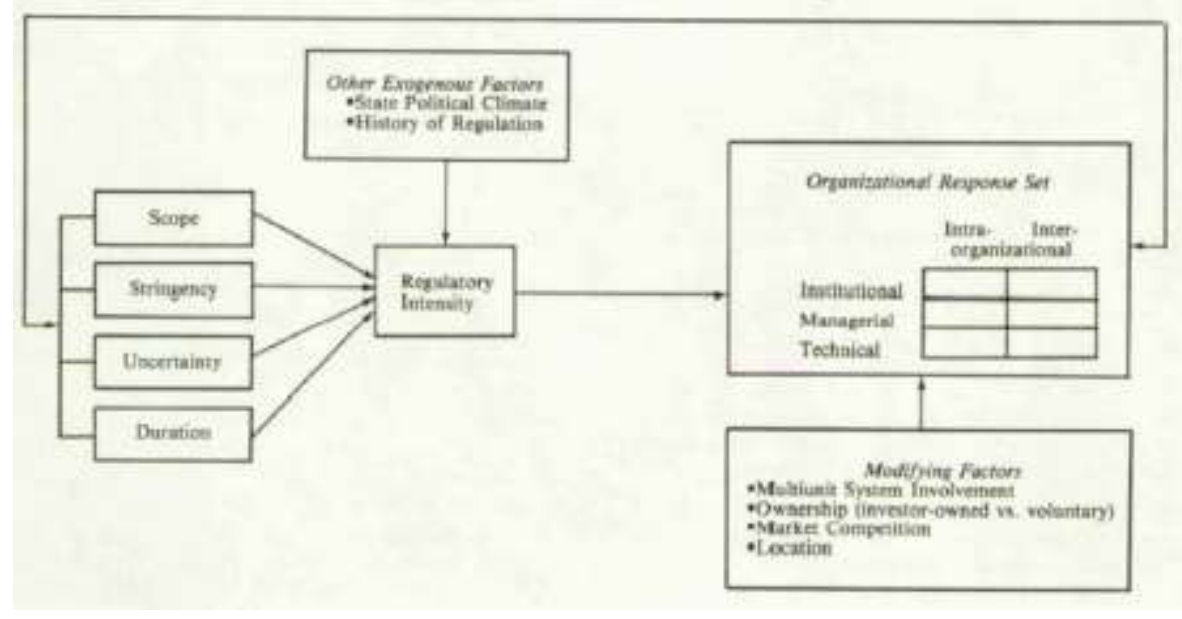

Figure 2. Theory of Organisational Responses to Regulation

While the concept of the regulation, in the form of a tax on services and products as considered by Cook et al. (1983), is not fully applicable to the regulation at hand, given that the EMIR and Basel III regulations are not directly impacting the products and services of the company, the concept of organizational response is helpful to categorize the response forms. Applying that on NFCs and the regulation of the OTC derivatives market suggests that the phase of intra-organisational level response has already been passed, given that EMIR and Basel III regulations have already been implemented. Responses that could be categorized in that phase are the lobbying of NFCs to be exempt from EMIR's clearing obligations when the derivative transaction is for hedging purposes as well as the CVA addition exemptions for transactions with NFCs for hedging purposes. Thus, as the regulation already overcame institutional level responses, organisations would now turn to managerial level responses, including the use of consultants, the change in degree of centralization, the upgrade of booking and trading systems etc. Given that the regulations are not directly impacting the products and services of the NFCs, the intensity of the regulation is rather mild, so that it is assumed not to lead to the necessity of technical level responses.

Therefore, it could be assumed that organisations will mainly rely on managerial level changes as response to the regulatory changes. Managerial level responses are connected to costs and additional investments in systems with no additional revenues coming from that investment. This, in general, would have negative consequences for the returns of the NFCs as they would decline. Therefore, the following is assumed:

P7. NFCs response on EMIR and Basel III regulations will mainly rely on intra-organisational managerial level changes.

P8. Managerial level responses will have negative consequences on returns of the NFCs, if those consequences cannot be compensated through other mechanisms. 


\section{Conclusion and Key Findings}

Corporate hedging practitioners are concerned with the impact of newly established regulations on their corporate hedging activities but fail to have a model on how the impact can be analysed and a concept of the the responses. A search of theoretical literature on corporate hedging revealed that there is a gap in current knowledge with regards to the impact of regulation on corporate hedging activities as well as NFCs' responses to the impact in terms of internal alignment. Given this gap, the review's first aim is to suggegst an initial model that can assist in analysing the impact of the regulatory actions on corporate hedging activities. The components of the model have been derived from existing theoretical models on the rationale for corporate to hedge and the optimal hedging strategy.

The second aim of the review is to suggest that concepts of organisation level responses, from the strategic management field, can also be applied on this topic and based on that suggest a conceptual framework that integrates the suggested initial model and organisation level responses, into one conceptual framework on impact of regulations on corporate hedging activities and organisational responses.

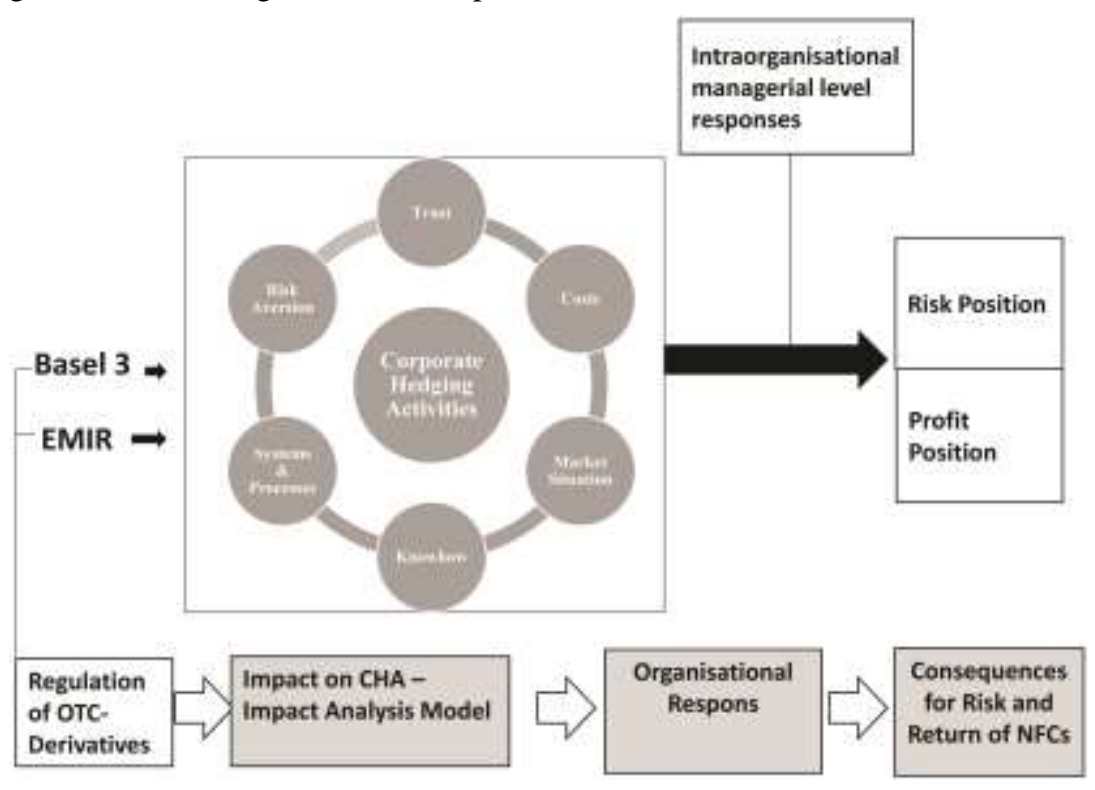

Figure 3. A priori conceptual framework

\section{References}

Adam. (2002). Risk management and the credit risk premium. Journal of banking \& finance, 26(2), 26. https://doi.org/10.1016/S0378-4266(01)00221-7

Adam, Fernando, C., \& Salas, J. (2015). Why do firms engage in selective hedging? Evidence from the gold mining industry. Journal of banking \& finance. https://doi.org/10.2139/ssrn.2613920

Adam, T. R. (2009). Capital expenditures, financial constraints, and the use of options. Journal of Financial Economics, 92(2), 238-251. https://doi.org/10.1016/j.jfineco.2008.04.007

Adler, M., \& Detemple, J. (1988). Hedging with futures and options. Studies in Banking and Finance, 5, 181-197.

Afza, T., \& Alam, A. (2011). Determinants of corporate hedging policies: A case of foreign exchange and interest rate derivative usage. African Journal of Business Management, 5(14), 5792-5797.

Alexandridis, G., Chen, Z., \& Zeng, Y. (2017). Financial Hedging and Corporate Investment Behavior: Evidence from Mergers and Acquisitions.

Ameer, R. (2010). Determinants of corporate hedging practices in Malaysia. International Business Research, 3(2), 120. https://doi.org/10.5539/ibr.v3n2p120

Andrews, K. R. (1971). The concept of corporate strategy. Homewood, Ill.,: Dow Jones-Irwin.

Ansoff, H. I. (1965). Corporate strategy; an analytic approach to business policy for growth and expansion. New York,: McGraw-Hill.

Arnold, M., Rathgeber, A., \& Stöckl, S. (2014). Determinants of Corporate Hedging: A (Statistical) Meta-Analysis. The Quarterly Review of Economics and Finance. https://doi.org/10.1016/j.qref.2014.05.002 
Arnold, R. S., \& Bohner, S. A. (1993). Impact analysis-towards a framework for comparison. Paper presented at the Software Maintenance, 1993. CSM-93, Proceedings. https://doi.org/10.1109/ICSM.1993.366933

Bajo, E., Barbi, M., \& Romagnoli, S. (2012). Optimal Corporate Hedging Using Options with Basis and Production Risk. Available at SSRN 2153840. https://doi.org/10.2139/ssrn.2153840

Bartram, S. M. (2000). Corporate risk management as a lever for shareholder value creation. Financial Markets, Institutions \& Instruments, 9(5), 279-324. https://doi.org/10.1111/1468-0416.00038

Bartram, S. M., Brown, G. W., \& Fehle, F. R. (2009). International evidence on financial derivatives usage. Financial management, 38(1), 185-206. https://doi.org/10.1111/j.1755-053X.2009.01033.x

Battermann, H. L., Braulke, M., Broll, U., \& Schimmelpfennig, J. (2000). The preferred hedge instrument. Economics Letters, 66(1), 85-91. https://doi.org/10.1016/S0165-1765(99)00180-9

Berk, J., \& DeMarzo, P. (2013). Corporate Finance (3 ed.): Pearson Education Limited.

Berkman, H., Bradbury, M. E., \& Magan, S. (1997). An international comparison of derivatives use. Financial management, 69-73. https://doi.org/10.2307/3666128

Bessembinder, H. (1991). Forward contracts and firm value: Investment incentive and contracting effects. Journal of financial and quantitative analysis, 26(04), 519-532. https://doi.org/10.2307/2331409

Bodnar, G. M., \& Gebhardt, G. (1999). Derivatives Usage in Risk Management by US and German Non-Financial Firms: A Comparative Survey. Journal of International Financial Management \& Accounting, 10(3), 153-187. https://doi.org/10.1111/1467-646X.00049

Bodnar, G. M., Giambona, E., Graham, J. R., \& Harvey, C. R. (2016). A view inside corporate risk management.

Breeden, D., \& Viswanathan, S. (1998). Why do firms hedge? An asymmetric information model. Fuqua School of Business, Working Paper.

Broll, U., \& Eckwert, B. (1999). Exchange rate volatility and international trade. Southern Economic Journal, 178-185. https://doi.org/10.2307/1060843

Brown, G. W., \& Toft, K. B. (2002). How firms should hedge. Review of Financial Studies, 15(4), 1283-1324. https://doi.org/10.1093/rfs/15.4.1283

Burgelman, R. A. (1983a). A Model of the Interaction of Strategic Behaviour, Corporate Context, and the Concept of Strategy. The Academy of Management Review, 8(1), 9. https://doi.org/10.5465/AMR.1983.4287661

Chattopadhyay, P., Glick, W. H., \& Huber, G. P. (2001). Organizational actions in response to threats and opportunities. Academy of management journal, 44(5), 937-955. https://doi.org/10.2307/3069439

Chaudhry, D., Iqbal, N., Mehmood, M. S., \& Mehmood, A. (2014). Determinants of corporate hedging policies and derivatives usage in risk management practices of non-financial firms. Wulfenia Journal, ISI Indexed, Impact Factor 0.267, 21(7), 293-310.

Chernenko, S., \& Faulkender, M. (2012). The two sides of derivatives usage: Hedging and speculating with interest rate swaps. Journal of financial and quantitative analysis, 46(06), 1727-1754. https://doi.org/10.1017/S0022109011000391

Cook, K., Shortell, S. M., Conrad, D. A., \& Morrisey, M. A. (1983). A theory of organizational response to regulation: the case of hospitals. Academy of Management Review, 8(2), 193-205. https://doi.org/10.2307/257746 https://doi.org/10.5465/AMR.1983.4284718

Cornell, B., \& Shapiro, A. C. (1987). Corporate stakeholders and corporate finance. Financial management, 5-14. https://doi.org/10.2307/3665543

DAI, \& VDT. (2012). Risikomangement mit Derivaten bei Unternehmen der Realwirtschaft - Verbreitung, Markttendenzen, Regulierungen (pp. 6). Frankfurt am Main: Deutsches Aktieninstitut e.V. / Verband Deutscher Treasurer e.V.

DeMarzo, P. M., \& Duffie, D. (1995). Corporate incentives for hedging and hedge accounting. Review of Financial Studies, 8(3), 743-771. https://doi.org/10.1093/rfs/8.3.743

Deng, S., Elyasiani, E., \& Mao, C. X. (2016). Derivatives-hedging, risk allocation and the cost of debt: Evidence from bank holding companies. The Quarterly Review of Economics and Finance.

Dionne, G. (2013). Risk Management: History, Definition, Critique. CIRRELT, Interuniversity Research Centre on 
Enterprise Networks Logistics and Transportation, 22. https://doi.org/10.2139/ssrn.2231635

Dobson, J., \& Soenen, L. (1993). Three Agency-Cost Reasons for Hedging Foreign Exchange Risk. Managerial Finance, 19(6), 9. https://doi.org/10.1108/eb013728

Dolde, W. (1995). Hedging, leverage, and primitive risk. Journal of Financial Engineering, 4(2).

Donnelly, J., \& Trochim, W. (2007). The research methods knowledge base. Ohio: Atomicdog Plublishing.

Donohoe, M. P. (2015). The economic effects of financial derivatives on corporate tax avoidance. Journal of Accounting and Economics, 59(1), 1-24. https://doi.org/10.1016/j.jacceco.2014.11.001

Ertugrul, M., Sezer, Ö., \& Sirmans, C. (2008). Financial leverage, CEO compensation, and corporate hedging: evidence from real estate investment trusts. The Journal of Real Estate Finance and Economics, 36(1), 53-80. https://doi.org/10.1007/s11146-007-9074-2

Fehle, F., \& Tsyplakov, S. (2005). Dynamic risk management: Theory and evidence. Journal of Financial Economics, 78(1), 3-47. https://doi.org/10.1016/j.jfineco.2004.06.013

Fok, R. C., Carroll, C., \& Chiou, M. C. (1997). Determinants of corporate hedging and derivatives: a revisit. Journal of Economics and Business, 49(6), 569-585. https://doi.org/10.1016/S0148-6195(97)00040-4

Frankenberger, S. (2006). Managing Regulatory Involvement on Corporate Strategy and Structure. Doctor of Business Administration, University of St. Gallen, St. Gallen.

Froot, K. A., Scharfstein, D. S., \& Stein, J. C. (1993). Risk managements coordinating corporate investment and financing policies. The Journal of Finance, 48(5), 1629-1658. https://doi.org/10.1111/j.1540-6261.1993.tb05123.x https://doi.org/10.2307/2329062

Gay, G. D., Nam, J., \& Turac, M. (2002). How firms manage risk: The optimal mix of linear and non-linear derivatives. Journal of Applied Corporate Finance, $14(4), \quad 82-93$. https://doi.org/10.1111/j.1745-6622.2002.tb00451.x

Gay, G. D., Nam, J., \& Turac, M. (2003). On the optimal mix of corporate hedging instruments: Linear versus nonlinear derivatives. Journal of Futures Markets, 23(3), 217-239. https://doi.org/10.1002/fut.10061

Glaum, M. (2002). The Determinants of selective exchange risk management - evidence from German non-financial corporations. Journal of Applied Corporate Finance, 14(4), 108-121. https://doi.org/10.1111/j.1745-6622.2002.tb00454.x

Goldberg, S. R., Godwin Kim Tritschler, J. H., \& Myung-Sun, C. A. (1998). On the determinants of corporate usage of financial derivatives. Journal of International Financial Management \& Accounting, 9(2), 132-166. https://doi.org/10.1111/1467-646X.00034

Graham, J. R., \& Smith, C. W. (1999). Tax incentives to hedge. The Journal of Finance, 54(6), 2241-2262. https://doi.org/10.1111/0022-1082.00187

Gupta, P. (2017). A Review of Corporate Hedging Models and Their Relevance in Corporate Finance. Theoretical Economics Letters, 7(02), 102. https://doi.org/10.4236/tel.2017.72010

Hart, S., \& Banbury, C. (1994). How strategy-making processes can make a difference. Strategic Management Journal, 15(4), 251-269. https://doi.org/10.1002/smj.4250150402

Haushalter, G. D. (2000). Financing policy, basis risk, and corporate hedging: Evidence from oil and gas producers. The Journal of Finance, 55(1), 107-152. https://doi.org/10.1111/0022-1082.00202

Haushalter, G. D., Heron, R. A., \& Lie, E. (2002). Price uncertainty and corporate value. Journal of Corporate Finance, 8(3), 271-286. https://doi.org/10.1016/S0929-1199(01)00043-8

Hopkin, P. (2017). Fundamentals of risk management: understanding, evaluating and implementing effective risk management. Kogan Page Publishers.

Huang, G. (2016). The determinants and dynamics of derivatives use in Australia.

Huang, G. P., \& Li, S. (2014). The Impact of Firm Characteristics and Manager Holdings on Hedging Decisions by Australian Mining Companies. Available at SSRN 2388009. https://doi.org/10.2139/ssrn.2388009

Huang, P. (2003). Two Essays on Corporate Hedging: The Choice of Instruments and Methods. University of Missouri. 
Jensen, M. C., \& Meckling, W. H. (1976). Theory of the firm: Managerial behavior, agency costs and ownership structure. Journal of Financial Economics, 3(4), 305-360. https://doi.org/10.1016/0304-405X(76)90026-X

Jensen, M. C., \& Smith, C. W. (1985). Stockholder, Manager, and Creditor Interests: Application of Agency Theory. In A. E. I. a. M. G. Subrahmanyam (Ed.), RecentAdvances in Corporate Finance (pp. 38). Homewood IL: Irwin.

Judge, A. (2002). Hedging and the use of derivatives: evidence from UK non-financial firms: Citeseer.

Judge, A. (2015). The determinants of foreign currency hedging by UK non-financial firms.

Mayers, D., \& Smith, C. W. (1982). On the corporate demand for insurance. Journal of Business, 281-296. https://doi.org/10.1086/296165

Mello, A. S., \& Parsons, J. E. (2000). Hedging and liquidity. Review of Financial Studies, 13(1), 127-153. https://doi.org/10.1093/rfs/13.1.127

Mian, S. L. (1996). Evidence on corporate hedging policy. Journal of financial and quantitative analysis, 31(3). https://doi.org/10.2307/2331399

Miloš Sprčić, D., Tekavčić, M., \& Šević, Ž. (2008c). Corporate risk management practices in Croatian companies. Ekonomski pregled, 59(7-8), 344-369.

Minton, B. A., \& Schrand, C. (1999). The impact of cash flow volatility on discretionary investment and the costs of debt and equity financing. Journal of Financial Economics, 54(3), 423-460. https://doi.org/10.1016/S0304-405X(99)00042-2

Mintzberg, H. (1987). The Strategy Concept. California Management Review, 30(1), 14.

Mnasri, M., Dionne, G., \& Gueyie, J.-P. (2013). How do firms hedge risks? Empirical evidence from US oil and gas producers: Empirical Evidence from US Oil and Gas Producers.

Moschini, G., \& Lapan, H. (1992). Hedging price risk with options and futures for the competitive firm with production flexibility. International Economic Review, 607-618. https://doi.org/10.2307/2527128

Nance, D. R., Smith, C. W., \& Smithson, C. W. (1993). On the determinants of corporate hedging. The Journal of Finance, 48(1), 267-284. https://doi.org/10.1111/j.1540-6261.1993.tb04709.x

Omar, A. B., Mohammad, K. N. B. T., \& Ahmad, N. B. (2017). Determinants of Hedging: A Reveiw of Theoretical Studies. Journal of Insurance and Financial Management, 2(5).

Özleblebici, Z., \& Çetin, Ş. (2015). The role of managerial perception within strategic management: an exploratory overview of the literature. Procedia-Social and Behavioral Sciences, 207, 296-305. https://doi.org/10.1016/j.sbspro.2015.10.099

Pfleeger, S. L., \& Atlee, J. (2006). System Engineering Theory and Practice. Higher Education Press.

Porter, M. (1979). The structure within industries and companies' performance. Review of Economics and Statistics, 61, 13. https://doi.org/10.2307/1924589

Rebello, M. J. (1995). Adverse Selection Costs and the Firm' s Financing and Insurance Decisions. Journal of Financial Intermediation, 4(1), 21-47. https://doi.org/10.1006/jfin.1995.1002

Saebi, T., Lien, L., \& Foss, N. J. (2016). What drives business model adaptation? The impact of opportunities, threats and strategic orientation. Long Range Planning.

Sang, L. T., Abu, Z. K., \& Osman, Z. (2013). The Determinants of Corporate Hedging. Journal of the Asian Academy of Applied Business, 2(1), 44-55.

Seamer, M., Choi, B. B., \& Doowon, L. (2015). Determinants of the rigour of enterprise risk management. Strategies: evidence from Australia.

Singh, A., \& Upneja, A. (2008). The determinants of the decision to use financial derivatives in the lodging industry. Journal of Hospitality \& Tourism Research. https://doi.org/10.1177/1096348008321364

Smith, C. W., \& Stulz, R. M. (1985). The determinants of firms' hedging policies. Journal of financial and quantitative analysis, 20(4), 391-405. https://doi.org/10.2307/2330757

Spanò, M. (2013). Theoretical explanations of corporate hedging. International Journal of Business and Social Research, 3(7), 18.

Sprčić, D. M. (2008a). The Derivatives as Financial Risk Management Instruments: The Case of Croatian and 
Slovenian Non-Financial Companies. Financial Theory and Practice, 31(4), 395-420.

Sprčić, D. M., Tekavčič, M., \& Šević, Ž. (2008b). A review of the rationales for corporate risk management: fashion or the need? International Journal of Economic Sciences and Applied Research, 1(1), 28.

Stulz, R. M. (1984). Optimal hedging policies. Journal of financial and quantitative analysis, 19(02), 127-140. https://doi.org/10.2307/2330894

Stulz, R. M. (1990). Managerial discretion and optimal financing policies. Journal of Financial Economics, 26(1), 3-27. https://doi.org/10.1016/0304-405X(90)90011-N

Stulz, R. M. (2013). How Companies Can Use Hedging to Crate Shareholder Value. Journal of Applied Corporate Finance, 25(4), 21-29. https://doi.org/10.1111/jacf.12038

Tansey, P., Spillane, J. P., \& Meng, X. (2014). Linking response strategies adopted by construction firms during the 2007 economic recession to Porter's generic strategies. Construction Management and Economics, 32(7-8), 705-724. https://doi.org/10.1080/01446193.2014.933856

Tufano, P. (1996). Who manages risk? An empirical examination of risk management practices in the gold mining industry. The Journal of Finance, 51(4), 1097-1137. https://doi.org/10.1111/j.1540-6261.1996.tb04064.x

Vest, J. R., \& Kash, B. A. (2016). Differing Strategies to Meet Information-Sharing Needs: Publicly Supported Community Health Information Exchanges Versus Health Systems' Enterprise Health Information Exchanges. The Milbank Quarterly, 94(1), 77-108. https://doi.org/10.1111/1468-0009.12180

Volberda, H. W., \& Elfring, T. (2001). Rethinking strategy. London: SAGE. 